\title{
Karakteristik kehamilan dengan luaran asfiksia saat lahir di RSUP Prof. Dr. R. D. Kandou Manado periode Januari - Desember 2014
}

\author{
${ }^{1}$ Eunike A. Pangemanan \\ ${ }^{2}$ John J. E. Wantania \\ ${ }^{2}$ Freddy W. Wagey
}

\author{
${ }^{1}$ Kandidat Skripsi Fakultas Kedokteran Universitas Sam Ratulangi Manado \\ ${ }^{2}$ Bagian Obstetri dan Ginekologi Fakultas Kedokteran Universitas Sam Ratulangi Manado \\ Email: Eunikep12040@ymail.com
}

\begin{abstract}
Asphyxia is a condition when a newborn baby does not breath spontaneously soon after birth. Maternal, labor, and fetal factors such as premature rupture of membrane, sectio caesarea, and fetal distress can cause asphyxia.. According to World Health Organization, in each year 3,6 million of 120 million newborns had asphyxia, and nearly one million babies died. According to data from the Indonesian Health Profile, low birth weight has the highest mortality risk $(40,15 \%)$ in newborn, followed by asphyxia during birth $(25,13 \%)$ in all hospitals in Indonesia. This study aimed to obtain the characteristics of pregnancy with asphyxia during birth in the Obstetric and Gynecology Department at Prof. Dr. R. D. Kandou Hosppital Manado during the period of January 2014 to December 2014. This was a descriptive retrospective study using medical record data of characteristics of pregnancy with asphyxia during birth in the labour room. The results showed that of 1273 cases of infant with asphyxia, pregnancies with complications had higher cases than pregnancies without complication. Among pregnancies without complication, there were $25 \%$ moderate asphyxia and $30 \%$ severe asphyxia newborns. Newborns with asphyxia were more common in primigravida than in multigravida. Based on age of mothers, asphyxia occured the most among mothers with the age range of 20-35 years (17.4\%). Based on gestational age, aterm pregnancy had the highest incidence rate in newborn asphyxia (20\%). Fetal distress was the highest cause of asphyxia in complicated pregnancy (18.3\%). Asphyxia occured more common in pregnancies with complications than in pregnancies without complications. Among pregnancies without complications, primigravida, age of mothers 20-35 years, and aterm pregnancy had the highest rate of newborn asphyxia. Fetal distress was the highest cause of asphyxia in complicated pregnancy.
\end{abstract}

Keywords: pregnancy, asphyxia

\begin{abstract}
Abstrak: Asfiksia adalah keadaan bayi yang tidak dapat bernapas spontan dan teratur segera setelah lahir. Faktor yang dapat menyebabkan asfiksia ialah faktor ibu, persalinan, dan janin; sebagai contoh ketuban pecah dini, seksio sesarea, dan gawat janin. Berdasarkan data World Health Organization, setiap tahunnya 3,6 juta bayi (3\%) dari 120 juta bayi baru lahir mengalami asfiksia, hampir satu juta bayi ini meninggal. Menurut data dari Profil Kesehatan Indonesia dari semua rumah sakit di Indonesia didapatkan kematian terbanyak ialah berat badan lahir rendah resiko kematian pertama tertinggi 40,15\% dan kedua tertinggi asfiksia saat lahir yaitu 25,13\%. Penelitian ini bertujuan untuk mengetahui karakteristik kehamilan dengan luaran asfiksia saat lahir di RSUP Prof. Dr. R. D. Kandou Manado periode Januari Desember 2014. Jenis penelitian ini ialah deskriptif retrospektif menggunakan catatan rekam medik di ruang VK Bagian Obstetri dan Ginekologi RSUP Prof. Dr. R. D. Kandou Manado. Hasil penelitian memperlihatkan dari 1273 kasus bayi asfiksia, kehamilan dengan penyulit
\end{abstract}


lebih banyak menderita asfiksia dibandingkan kehamilan tanpa penyulit. Penyulit kehamilan pada asfiksia derajat sedang $75 \%$ dan asfiksia derajat berat $70 \%$. Tanpa penyulit kehamilan yaitu pada asfiksia derajat sedang 25\% dan asfiksia derajat berat 30\%. Didapatkan data tanpa penyulit kehamilan, primigravida $(14,5 \%)$ lebih banyak menderita asfiksia dibandingkan multigravida. Berdasarkan umur ibu, bayi yang mengalami asfiksia terbanyak pada umur ibu 20-35 tahun (17,4\%). Berdasarkan usia kehamilan, usia kehamilan aterm merupakan angka kejadian tertinggi pada bayi asfiksia (20\%). Data penyulit kehamilan didapatkan gawat janin merupakan angka tertinggi menderita asfiksia (18,3\%). Penyulit kehamilan lebih banyak menderita asfiksia dibandingkan tanpa penyulit kehamilan. Kehamilan tanpa penyulit didapatkan primigravida, umur ibu 20-35 tahun, dan usia kehamilan atterm merupakan penderita asfiksia terbanyak. Kehamilan dengan penyulit didapatkan gawat janin merupakan penderita asfiksia terbanyak.

Kata kunci: kehamilan, asfiksia

Asfiksia adalah keadaan bayi yang tidak dapat bernapas spontan dan teratur segera setelah lahir, karena bayi tidak dapat memasukkan oksigen dan tidak dapat mengeluarkan karbondioksida dari tubuhnya dan menimbulkan akibat buruk dalam kehidupan lebih lanjut yaitu meninggalnya bayi. ${ }^{1}$ Gangguan tersebut dapat disebabkan karena adanya obstruksi pada saluran pernapasan dan gangguan yang diakibatkan karena terhentinya sirkulasi pernapasan. ${ }^{1,2}$

Asfiksia merupakan kelanjutan dari hipoksia ibu dan janin yang disebabkan oleh berbagai faktor. Asfiksia dikarenakan masalah yang berkaitan dengan keadaan ibu seperti partus lama, plasenta previa, solusio plasenta, preeklamsia, eklamsia, ketuban pecah dini, kehamilan postterm, penyakit kronik ibu, dan his yang terlampau kuat. His yang terlampau kuat dapat menyebabkan gangguan sirkulasi uteroplasenter yang dapat mengganggu aliran darah yang mengangkut oksigen dari ibu ke janin yang dapat mengakibatkan asfiksia. Pada faktor janin yaitu bayi preterm, gawat janin, bayi kembar, dan kelainan tali pusat. Pada faktor asfiksia yang berkaitan dengan persalinan sulit seperti letak sungsang, bayi kembar, distosia bahu, dan kelainan kongenital. Perlunya mengetahui faktor-faktor tersebut untuk mengetahui derajat asfiksia, mendiagnosis dan melakukan penanganan serta pencegahan pada ibu yang memiliki faktor resiko bayi menderita asfiksia. ${ }^{3}$

Kejadian asfiksia merupakan penyebab mortalitas dan morbiditas di negara maju dan di negara berkembang. Berdasarkan data World Health Organization (WHO), setiap tahunnya 3,6 juta bayi (3\%) dari 120 juta bayi baru lahir mengalami asfiksia, hampir satu juta bayi ini meninggal dan pada survey WHO tahun 2002 dan 2004, kematian bayi baru lahir disebabkan oleh asfiksia sebesar (27\%). ${ }^{1}$ Angka kematian bayi baru lahir di Indonesia menurut Survey Departemen Kesehatan Indonesia tahun 2002 dan tahun 2003 adalah 20/1.000 kelahiran hidup, salah satu penyebab utama kematian bayi baru lahir adalah asfiksia. ${ }^{2}$ Pada survei Departemen Kesehatan Indonesia tahun 2007 sebanyak 40/1000 kelahiran hidup. Pada tahun 2008-2012 32/1.000 kelahiran hidup angka ini telah turun dari survei Departemen Kesehatan Indonesia tahun 2007, namun penurunan ini masih jauh dari target Millenium Development Goals tahun 2015 dimana angka kematian bayi diharapkan turun menjadi 23/1.000 kelahiran hidup. ${ }^{3}$ Dari seluruh kematian bayi, sebanyak $47 \%$ meninggal pada masa neonatal dan setiap 5 menit terdapat satu neonatus yang meninggal. Penyebab kematian neonatal di Indonesia pertama ialah berat badan lahir rendah 29\% dan penyebab kematian kedua ialah asfiksia sebanyak 27\%.,

Menurut data Profil Kesehatan Indonesia dari semua rumah sakit di Indonesia didapatkan kematian terbanyak ialah berat badan lahir rendah resiko kematian pertama tertinggi 40,15\% dan kedua tertinggi asfiksia saat lahir yaitu 
25,13\%. ${ }^{5}$ Data dari Dinas Kesehatan Provinsi Kalimantan Selatan menunjukkan angka kematian bayi pada tahun 2012 berjumlah 816 bayi dan pada tahun 2013 berjumlah 727 bayi dengan penyebab terbanyak ialah berat badan lahir rendah 258 bayi, asfiksia 178 bayi, tetanus 13 bayi dan penyebab lain berjumlah 185 bayi. $^{3}$ Berdasarkan data Dinas Kesehatan Provinsi Kepulauan Riau pada tahun 2011 jumlah kelahiran yaitu 156.348 orang dengan jumlah kematian bayi karena asfiksia yaitu 66 bayi (23,91\%) dan pada tahun 2012 jumlah kelahiran 142.285 orang dengan jumlah kematian bayi karena asfiksia yaitu 66 bayi $(25,58 \%)^{6}$

Data di atas menunjukkan bahwa masih tingginya mortalitas bayi dengan asfiksia saat lahir. Penelitian ini bertujuan untuk mendapatkan karakteristik kehamilan dengan luaran asfiksia saat lahir di Bagian Obstetri dan Ginekologi RSUP Prof. Dr. R. D. Kandou Manado periode Januari Desember peiode 2014.

\section{METODE PENELITIAN}

Jenis penelitian ini deskriptif retrospektif dengan memanfaatkan data Rekam Medik RSUP Prof. Dr. R. D. Kandou Manado periode Januari - Desember 2014. Subjek penelitian ialah seluruh pasien yang dirawat diruang VK Bagian Obstetri dan Ginekologi RSUP Prof. Dr. R. D. Kandou Manado yang mengalami kehamilan dengan luaran asfiksia saat lahir periode Januari - Desember 2014.

Variabel yang digunakan ialah jumlah bayi berdasarkan kondisi saat lahir, jumlah penyulit kehamilan yaitu ibu melahirkan dengan sectio caesarea, ekstrasi vakum, dan ekstrasi forsep dan tanpa penyulit kehamilan yaitu ibu melahirkan spontan letak belakang kepala berdasarkan derajat asfiksia, data ibu melahirkan spontan letak belakang kepala dengan luaran asfiksia saat lahir berdasarkan karakteristik gravida, umur ibu, beserta usia kehamilan, dan data lima penyulit kehamilan terbanyak dengan luaran asfiksia saat lahir.

\section{HASIL PENELITIAN}

Hasil penelitian deskriptif retrospektif yang dilakukan di ruangan VK bagian Obstetri dan Ginekologi RSUP Prof Dr. R. D. Kandou Manado periode Januari Desember 2014 memperlihatkan jumlah pasien yang dirawat 3.038 orang.

Dari Tabel 1 diperoleh distribusi sejumlah 3.038 bayi berdasarkan kondisi saat lahir terdiri dari 1.701 (56\%) bayi bugar, 1.273 (41,9\%) bayi asfiksia, dan 64 (2,1\%) bayi mati.

Tabel 1. Distribusi jumlah bayi berdasarkan kondisi saat lahir.

\begin{tabular}{ccc}
\hline Kondisi Bayi & $\mathrm{N}$ & $\%$ \\
\hline Bayi Bugar & 1.701 & 56 \\
Bayi Asfiksia & 1.273 & 41,9 \\
Bayi Mati & 64 & 2,1 \\
Total & 3.038 & 100 \\
\hline
\end{tabular}

Tabel 2 memperlihatkan distribusi penyulit kehamilan yaitu ibu melahirkan dengan sectio caesarea, ekstrasi vakum, dan ekstrasi forsep, dan tanpa penyulit kehamilan yaitu ibu melahirkan spontan letak belakang kepala berdasarkan derajat asfiksia. Didapatkan data penyulit kehamilan dengan luaran asfiksia saat lahir pada asfiksia derajat sedang 783 pasien (75\%) dan data penyulit kehamilan dengan luaran asfiksia saat lahir pada asfiksia derajat berat 159 pasien (70\%). Data tanpa penyulit kehamilan dengan luaran asfiksia saat lahir pada asfiksia derajat sedang 262 pasien (25\%) dan data tanpa penyulit kehamilan dengan luaran asfiksia saat lahir pada asfiksia derajat berat 69 pasien (30\%).

Tabel 2. Jumlah penyulit kehamilan yaitu ibu melahirkan dengan sectio caesarea, ekstrasi vakum, dan ekstrasi forsep dan tanpa penyulit kehamilan yaitu ibu melahirkan spontan letak belakang kepala berdasarkan derajat asfiksia.

\begin{tabular}{lllll}
\hline Kehamilan & AS & $\%$ & AB & $\%$ \\
\hline Penyulit (+) & 783 & 75 & 159 & 70 \\
Penyulit (-) & 262 & 25 & 69 & 30 \\
\hline
\end{tabular}

Ket: AS, asfiksia derajat sedang; AB, asfiksia derajat berat 
Tabel 3 memperlihatkan data ibu melahirkan spontan letak belakang kepala dengan luaran asfiksia saat lahir berdasarkan karakteristik gravida, umur ibu, dan usia kehamilan. Didapatkan 185 (14,5\%) ibu dengan primigravida dan146 (11,5\%. ibu dengan multigravida. Dari data umur diperoleh hasil umur $<20$ tahun 69 pasien (5,4\%); umur 20-35 tahun 222 pasien (17,4\%); dan umur $>35$ tahun 40 pasien $(3,1 \%)$. Dari data usia kehamilan diperoleh preterm 76 pasien (6\%), aterm 255 pasien (20\%), dan postterm tidak ada.

Tabel 3. Data ibu melahirkan spontan letak belakang kepala dengan luaran asfiksia saat lahir berdasarkan karakteristik gravida, umur ibu, dan usia kehamilan.

\begin{tabular}{lcc}
\hline $\begin{array}{l}\text { Tanpa penyulit } \\
\text { kehamilan }\end{array}$ & $\mathrm{N}$ & $\%$ \\
\hline Gravida & & \\
$\quad \begin{array}{c}\text { Primigravida } \\
\text { Multigravida }\end{array}$ & 185 & 14,5 \\
$\begin{array}{c}\text { Umur ibu } \\
<20 \text { tahun }\end{array}$ & 69 & 11,5 \\
$20-35$ tahun & 222 & 17,4 \\
$\quad>35$ tahun & 40 & 3,1 \\
Usia kehamilan & & \\
$\quad$ Preterm & 76 & 6 \\
Aterm & 255 & 20 \\
Postterm & 0 & 0 \\
\hline
\end{tabular}

Tabel 4 memperlihatkan data lima penyulit kehamilan terbanyak dengan luaran asfiksia saat lahir yaitu gawat janin 248 pasien (18,3\%), ketuban pecah dini 92 pasien $(6,8 \%)$, letak sungsang 74 pasien (5,5\%), plasenta previa 37 pasien $(2,7 \%)$, dan superimposed preeklamsi 36 pasien $(2,6 \%)$.

Tabel 4. Data lima penyulit kehamilan terbanyak dengan luaran asfiksia saat lahir.

\begin{tabular}{lcc}
\hline Penyulit Kehamilan & $\mathrm{N}$ & $\%$ \\
\hline Gawat Janin & 248 & 18,3 \\
Ketuban Pecah Dini & 92 & 6,8 \\
Letak Sungsang & 74 & 5,5 \\
Plasenta Previa & 37 & 2,7 \\
Superimposed & 36 & 2,6 \\
Preeklampsia & & \\
\hline
\end{tabular}

\section{BAHASAN}

Hasil penelitian deskriptif retrospektif yang dilakukan di ruangan VK bagian Obstetri dan Ginekologi RSUP Prof Dr. R. D. Kandou Manado periode Januari Desember 2014 mendapatkan jumlah bayi yang dilahirkan 3.038, terdiri dari bayi bugar 1.701 pasien (56\%) (bayi bugar adalah bayi yang tidak membutuhkan perawatan medis) dan bayi asfiksia 1.273 pasien (41,9\%), American Academy of Pediatrics dan American College of Obstetrician and Gynecologyst menetapkan empat kriteria yang harus ada dalam mendefinisikan asfiksia, yaitu: asidosis metabolik atau asidosis campuran dengan $\mathrm{pH}<7,00$ pada arteri umbilikalis, nilai apgar 0-3 pada menit kelima atau lebih, manifestasi neurologi segera pada periode perinatal seperti kejang, hipotonus, koma atau ensefalopati hipoksia iskemi, dan ada bukti disfungsi multiorgan pada periode neonatal. $^{7,8}$ Dari 64 bayi mati (2,1\%), terdapat dua penyebab kematian bayi yaitu endogen dan eksogen. Kematian bayi endogen disebabkan oleh faktor-faktor yang dibawa anak sejak lahir, yang diperoleh dari orang tuanya pada saat konsepsi. Kematian bayi yang disebabkan dari kondisi bayinya sendiri yaitu berat badan lahir rendah, bayi preterm, kelainan kongenital, dan asfiksia. Kematian bayi eksogen disebabkan oleh factor-faktor yang bertalian dengan pengaruh lingkungan luar. Kematian bayi dapat diakibatkan dari kurangnya kesadaran akan kesehatan ibu dimana ibu jarang memeriksakan kandungannya, hamil diusia muda, jarak yang terlalu sempit, hamil di usia tua, kurangnya asupan gizi bagi ibu dan bayinya, makanan yang dikonsumsi ibu tidak bersih, fasilitas sanitasi dan higienitas yang tidak memadai ${ }^{9}$ (Tabel 3).

Dari Tabel 4 jumlah penyulit kehamilan yaitu ibu melahirkan dengan sectio caesarea, ekstrasi vakum, dan ekstrasi forsep, dan tanpa penyulit kehamilan yaitu ibu melahirkan spontan letak belakang kepala berdasarkan derajat asfiksia. Didapatkan penyulit kehamilan dengan luaran asfiksia pada asfiksia derajat 
sedang 783 pasien (75\%) dan penyulit kehamilan dengan luaran asfiksia derajat berat yaitu 159 pasien (70\%). Penyulit kehamilan yaitu kehamilan dengan tindakan seperti seksio sesarea dan ekstraksi vakum pada persalinan dengan letak sungsang dan juga pada persalinan sulit lainya. Penyulit kehamilan dengan faktor ibu sehingga bayi mengalami asfiksia saat lahir seperti ketuban pecah dini, plasenta previa, preeklamsia, eklamsia, penyakit kronis pada ibu seperti hipertensi dan penyakit jantung. Penyulit kehamilan dengan faktor janin sehinggan bayi mengalami asfiksia yaitu gawat janin, bayi preterm, bayi kembar, dan kelainan kongenital. Menurut teori dari Mulastin mengatakan bahwa penyebab terjadinya asfiksia dengan adanya penyulit kehamilan karena digunakan alat dan adanya penggunaan obat bius dalam operasi. Salah satu faktor penyebab terjadinya asfiksia adalah perdarahan intrakranial yang menyebabkan terganggunya proses sirkulasi oksigen ke otak. ${ }^{4}$ Berdasarkan hasil tanpa penyulit kehamilan pada asfiksia derajat sedang 262 pasien (25\%) dan tanpa penyulit kehamilan pada asfiksia derajat berat 69 pasien (30\%). Menurut teori dari Mulastin mengatakan bahwa tanpa penyulit kehamilan dapat terjadi asfiksia karena ada penekanan saat terjadi mekanisme persalinan berlangsung meliputi penurunan kepala, fleksi, rotasi dalam, ekstensi, rotasi luar dan ekspulsi. ${ }^{4}$

Data Tabel 5 ibu melahirkan spontan letak belakang kepala dengan luaran asfiksia saat lahir berdasarkan gravida, umur ibu, dan usia kehamilan. Diperoleh data primigravida 185 pasien (14,5\%) dan ibu dengan multigravida 146 pasien (11,5\%). Menurut hasil jurnal dari Lismiati bahwa data ibu primigravida lebih banyak dari multigravida, ${ }^{10}$ hasil ini sesuai dengan penelitian yang dilakukan. Berdasarkan data umur diperoleh hasil umur ibu $<20$ tahun 69 pasien $(5,4 \%)$, data umur ibu 20 35 tahun 222 pasien (17,4\%), dan umur ibu $>35$ tahun 40 pasien (3,1\%). Menurut teori dari jurnal pediatri faktor resiko asfiksia dikelompokkan berdasarkan kelompok resiko tinggi dan resiko rendah yang mengalami asfiksia dari faktor ibu dan bayi. Resiko tinggi mengalami asfiksia, meliputi umur ibu $<18$ tahun dan $>35$ tahun. $^{11}$ Hal ini tidak sesuai dengan penelitian. Berdasarkan data usia kehamilan diperoleh preterm 76 (6\%), menurut Tjandrarini dan Djaja ${ }^{12}$ mengatakan bahwa kondisi pada bayi baru lahir yang menyebabkan kematian di Indonesia umumnya yaitu bayi preterm. Bayi yang lahir preterm organ-organ tubuhnya belum sempurna hal ini menyebabkan sistem pernapasan khususnya paru-paru bayi belum bekerja secara optimal, surfaktan masih kurang sehingga kemungkinan paru mengalami gangguan perkembangan, otot pernapasan masih lemah sehingga tangis bayi preterm terdengar lemah dan merintih akibatnya bayi bisa mengalami asfiksia. ${ }^{13}$ Berdasarkan usia kehamilan aterm 255 pasien (20\%), menurut teori jurnal Ilmu Kesehatan masa kehamilan dimulai dari konsepsi sampai lahirnya janin, lamanya hamil normal adalah 280 hari dihitung dari hari pertama haid terakhir dan dibagi dalam tiga triwulan yaitu triwulan pertama dimulai dari konsepsi sampai tiga bulan, triwulan kedua dari bulan keempat sampai enam bulan, triwulan ketiga dari bulan ketujuh sampai sembilan bulan. ${ }^{14}$ Menurut penulis terjadinya asfiksia terbanyak pada usia kehamilan aterm dikarenakan faktor lain seperti faktor usia ibu dan faktor gravida ibu. Data usia kehamilan postterm tidak ada, menurut WHO kehamilan postterm kehamilan 42 minggu lebih yang dihitung berdasarkan hari pertama haid terakhir. Kehamilan postterm merupakan resiko terjadinya hipoksia janin karena plasenta sudah mengalami proses penurunan struktural dan fungsional. ${ }^{15}$ Menurut teori dari Nurmawayati D mengatakan, pada kehamilan postterm terjadi penurunan oksitosin sehingga tidak menyebabkan adanya his, dan terjadi penundaan persalinan. Permasalahan kehamilan postterm adalah plasenta tidak adekuat dalam memberikan nutrisi dan dalam pertukaran karbondioksida dengan 
oksigen sehingga janin mempunyai resiko asfiksia sampai kematian dalam rahim. ${ }^{16}$

Hasil Tabel 6 data lima penyulit kehamilan dengan luaran asfiksia saat lahir, diperoleh hasil gawat janin 248 pasien (18,3\%) menurut teori dari jurnal Gaster kehamilan postterm dapat menyebabkan gawat janin karena fungsi plasenta mencapai puncaknya pada kehamilan 38 minggu dan kemudian mulai menurun terutama setelah 42 minggu, hal ini dapat dibuktikan dengan penurunan kadar estriol dan plasental laktogen. Rendahnya fungsi plasenta dapat menyebabkan gangguan pernapasan janin dan gangguan sirkulasi bayi setelah lahir sehingga terjadi asfiksia. ${ }^{7}$

Data penyulit kehamilan pada ketuban pecah dini 92 pasien (6,8\%). Kejadian ketuban pecah dini pada ibu hamil membahayakan janin karena air ketuban dapat menyebabkan hipoksia atau keracunan pada janin sehingga dapat menyebabkan kematian janin. ${ }^{17}$ Didapatkan hasil data komplikasi letak sungsang 74 pasien (5,5\%). Letak sungsang adalah bayi letaknya sesuai dengan badan ibu, kepala berada pada fundus uteri sedangkan bokong merupakan bagian terbawah di daerah simfisis, letak sungsang merupakan lahirnya bokong dan bagian tubuh janin yang tidak selalu dapat diikuti dengan kepala, hal tersebut dapat menyebabkan asfiksia. $^{18}$ Berdasarkan data penyulit kehamilan pada plasenta previa 37 pasien (2,7\%) menurut teori dari jurnal maternity and neonatal mengatakan bahwa plasenta previa merupakan salah satu penyulit pada ibu hamil yang dapat menyebabkan anemia sampai syok, sedangkan untuk janin dapat menimbulkan asfiksia sampai kematian janin dalam rahim. ${ }^{1}$ Didapatkan hasil data penyulit kehamilan dengan superimposed preeklamsi 36 (2,6\%). Superimposed preeklamsi adalah preeklamsi yang terjadi pada wanita yang menderita penyakit hipertensi vaskuler kronis, tekanan darah yang meningkat mengakibatkan pembuluh darah mengalami vasokonstriksi akibatnya suplai darah ke jaringan tubuh akan berkurang sehingga dapat menyebabkan asfiksia $^{19}$ Dapat dilihat dari hasil, risiko tinggi mengalami bayi asfiksia saat lahir terdapat pada riwayat obstetri buruk selama kehamilan.

Keterbatasan penelitian ini tidak semua data pada tahun 2014 di jadikan sampel karena kurangnya data pasien.

\section{SIMPULAN}

Dari hasil penelitian yang dilakukan di ruang VK Bagian Obstetri dan Ginekologi RSUP Prof. Dr. R. D. Kandou Manado didapatkan:

1. Jumlah kondisi bayi bugar terbanyak.

2. Bayi dengan penyulit kehamilan lebih banyak menderita asfiksia dibandingkan dengan tanpa penyulit kehamilan.

3. Data tanpa penyulit kehamilan dengan luaran asfiksia saat lahir didapatkan primigravida, umur ibu 20-35 tahun dan kehamilan aterm merupakan kejadian asfiksia tertinggi.

4. Data penyulit kehamilan dengan luaran asfiksia saat lahir terbanyak ialah gawat janin.

\section{SARAN}

1. Untuk institusi kesehatan diharapkan untuk meningkatkan pelayanan kesehatan ibu dan anak, khususnya pada penanganan gawat darurat yaitu penyediaan alat resusitasi pada setiap persalinan termasuk juga jenis persalinan normal.

2. Untuk responden diharapkan dengan adanya penelitian ini semua ibu lebih menjaga kesehatan dengan melakukan pemeriksaan kehamilan saat hamil sehingga mengantisipasi bayi mengalami resiko asfiksia.

\section{DAFTAR PUSTAKA}

1. Herawati R. Faktor-faktor yang menyebabkan terjadinya asfiksia neonatorum pada bayi baru lahir. Maternity and Neonatal. 2013;1:7582.

2. Widaryati, Anggraeni, Murtutik L, Astuti F. The coherence factors of asphyxia happen to the neonatorum. Ilmu Keperawatan Indonesia. 2011;1:1-6.

3. Maolinda W, Salmarini D, Mariani. 
Hubungan persalinan tindakan dengan kejadian asfiksia neonatorum. Dinamika Kesehatan. 2015;13:14650.

4. Mulastin. Hubungan jenis persalinan dengan kejadian asfiksia neonatorum. Kesehatan dan Budaya. 2014;7:1-2.

5. Indrasanto D. Profil Kesehatan Indonesia (1st ed). Jakarta: Departemen Kesehatan Republik Indonesia, 2011; p. 15-6.

6. Respatiningrum, Nainggolan $M$, Lestari R. Hubungan kejadian asfiksia neonatorum dengan perkembangan bayi usia 6-12 bulan. Kebidanan. 2013;1-23.

7. Hartatik D, Yuliaswati E. Pengaruh umur kehamilan pada bayi baru lahir dengan kejadian asfiksia. Gaster. 2013;10:71-72.

8. Alhadar A, Amir I, Oswari H, Windiastuti E. Korelasi nilai apgar menit kelima kurang dari tujuh dengan kadar transaminase serum pada bayi baru lahir. Pediatri. 2011;12:191.

9. Wandira A, Indawati R. Faktor penyebab kematian. Biometrika dan Kependudukan. 2012;1:33-42.

10. Lismiati L. Hubungan Ketuban Pecah Dini dengan ejadian Asfiksia Neonatorum. OPAC. 2013;1:5-6.

11. Wiradharma, Kardana, Dharma A. Resiko asfiksia pada ketuban pecah dini. Pediatri. 2013;14:316-9.

12. Tjandrarini H, Djaja S. Aspek kehamilan dan persalinan pada kematian neonatal akibat asfiksia lahir sebelum dan setelah intervensi manajemen asfiksia. Ekologi Kesehatan. 2009;3:1057.

13. Astuti W, Handayani E, Parmudikayanti A. Usia kehamilan tidak aterm menyebabkan asfiksia bayi baru lahir. Bhamada. 2015;6:129-35.

14. Diny, Masruroh. Hubungan pengetahuan ibu hamil tentang ketidaknyamanan kehamilan dengan sikap dalam mengatasi ketidaknyamanan kehamilan. Ilmiah Kesehatan. 2012;1:4.

15. Dianggra P. Perbandingan induksi misoprostol dengan induksi oksitosin terhadap lama persalinan pada kehamilan postterm. Kedokteran Indonesia. 2011;1:131.

16. Nurmayawati D. Hubungan kehamilan lewat waktu (postterm) dengan kejadian asfiksia pada bayi baru lahir. Kebidanan Komunitas. 2014;7:19-25.

17. Lestari R, Wardani Y. Induksi persalinan dengan kejadian asfiksia pada bayi baru lahir. Ilmu kebidanan. 2013;1:16-21.

18. Sarwono. Ilmu kebidanan (4th ed). Jakarta: PT Bina Pustaka Sarwono Prawirohardjojo, 2010; p. 588.

19. Pramono A. Kadar asam urat serum pada kehamilan trimester II dan III sebagai prediktor kejadian asfiksia [Tesis]. Semarang: Universitas Diponogoro; 2012. 